\section{Inactivation of food borne pathogens by lipid fractions of culinary condiments and their nutraceutical properties}

\author{
Ayeza Naeem, ${ }^{1}$ Tanveer Abbas, ${ }^{1}$ \\ Tahira Mohsin Ali, ${ }^{2}$ Abid Hasnain ${ }^{2}$ \\ ${ }^{1}$ Department of Microbiology; \\ ${ }^{2}$ Department of Food Science and \\ Technology, University of Karachi, \\ Karachi, Pakistan
}

\begin{abstract}
Lipid fraction from four different culinary condiments namely black seed (Nigella sativa), fennel seeds (Foeniculum vulgare), bay leaf (Laurus nobilis) and coriander seeds (Coriandrum sativum) were investigated for total phenolic content, antioxidant activity, total flavonoid content, total flavonol content and antibacterial attributes. Antimicrobial properties were determined against food-borne bacteria through agar well diffusion, drop agar diffusion, macrobroth dilution with simultaneous determination of their minimum inhibitory concentrations and changes in cellular morphology was analyzed through Scanning electron microscopy. Generally, ethanolic lipid fractions were more effective bioactively as compared to methanolic LFs. Parallel results were obtained for antibacterial activities with the highest antibacterial activities exhibited by ethanolic LFs. The results positively support the use of these lipid fractions in generating new systems to inhibit bacterial growth, extend the shelf life and enhance the safety of the packaged food product. The examined oils can also be used for therapeutic purposes.
\end{abstract}

\section{Introduction}

Food poisoning is still a major apprehension simultaneously for consumers and the food industry regardless of the use of numerous conservation procedures. Due to the resistance that pathogens build to counter antibiotics, there is an increasing awareness to make use of natural antibacterial derivatives for food preservation and safety, like extracts of culinary herbs and condiments. ${ }^{1}$

Lipid fractions have since quite a while ago served as enhancing flavors in food and drinks, and because of their versatile composition of antimicrobial complexes, they have potential for food preservation. ${ }^{2}$ Various pharmaceutical and biological activities like, antibacterial, antifungal, anticancer, antimutagenic, antidiabetic, antiviral, anti-inflammatory, and antiprotozoal properties are assigned to them. ${ }^{3}$ The antimicrobial activity of lipid fractions is allotted to many terpenoid and phenolic compounds, which also in crude form have been shown to possess antibacterial or antifungal activity. ${ }^{4}$ The antibacterial properties of these compounds are in part related to their lipophilic attribute, leading to accumulation in membranes and to subsequent membrane-associated events such as energy depletion. ${ }^{5}$ However, there are often large variances in the stated antibacterial activity of oils from the same source. The justification for this diversity can be due to the geographical sources, the harvesting seasons, the genotype, the climate, the drying and the distilled part of the plant which are significant factors influencing the chemical composition and relative magnitudes of the individual elements in the lipid fractions of the plant. Also, several lipid fraction components show noteworthy antimicrobial characteristics when tested discretely. ${ }^{6}$ However, there is confirmation that lipid fractions are more intensely antimicrobial than their major antimicrobial constituents. ${ }^{7}$

The present study deals with the isolation of lipid fractions of Nigella sativa linn. (Family: Ranunculaceae), Coriandrum sativum L. (Family: Apiaceae Umbelliferae), Foeniculum vulgare Miller (Family: Apiaceae) and Laurus nobilis L. (Family: Lauraceae) and to compare these lipid fractions in terms of their antioxidant, total phenolic, total flavonoid and total flavonol contents. Moreover, the antimicrobial activities of these fractions were also investigated using different assays against five food borne pathogens.

\section{Materials and Methods}

\section{Chemicals}

All chemicals used in this research were of analytical grade and were obtained from Sigma Aldrich (Sigma Aldrich GmbH, Sternheim, Germany). Mueller Hinton agar and broth were purchased from Thermo Scientific ${ }^{\mathrm{TM}}$ Oxoid $^{\mathrm{TM}}$

\section{Seed material}

Four different dried spices i.e. black seeds, fennel seeds, coriander seeds and bay leaf were purchased from a local market during the month of February 2015. The spices were ground to fine powder using a Waring ${ }^{\circledR}$ Spice Grinder WSG60K and preserved in zip-lock ${ }^{\circledR}$ bags and stored at freezing temperature until analyzed.
Correspondence: Ayeza Naeem, Department of Microbiology, University of Karachi, 75270 Karachi, Pakistan.

E-mail: ayeza.naeem@gmail.com

Acknowledgments: the authors would like to thank Miss Tahira Mohsin Ali for basically perusing the manuscript and worthwhile discussions.

Key words: Black seed; Fennel seed; Coriander seeds; Bay leaf; lipid fractions.

Contributions: the authors contributed coequally.

Conflict of interest: the authors declare no potential conflict of interest.

Funding: none

Received for publication: 24 October 2017. Accepted for publication: 1 December 2017.

This work is licensed under a Creative Commons Attribution NonCommercial 4.0 License (CC BY-NC 4.0).

(C) Copyright A. Naeem et al., 2018

Licensee PAGEPress, Italy

Microbiology Research 2018; 9:7465

doi:10.4081/mr.2018.7465

\section{Extraction of lipid fractions}

Lipid fractions were extracted by the solvent extraction method as proposed by Cheikh-Rouhou et al. $2007^{8}$ using methanol and ethanol as an extractant. Dried spice powder $(50 \mathrm{~g})$ was extracted separately with $250 \mathrm{ml}$ of each solvent. After mixing in a shaking water bath for four hours at $40^{\circ} \mathrm{C}$, the mixture was centrifuged for 15 minutes at $1000 \mathrm{~g}$. The supernatant was filtered through a Whatman ${ }^{\circledR}$ No. 2 filter paper. The extraction procedure was repeated twice and the solvent was removed using a rotary evaporator (Rotavapor R-210, Buchi laboratories, Switzerland) at $40^{\circ} \mathrm{C}$. The concentrated lipid fraction was pooled in an amber colored bottle and tightly sealed and stored at freezing temperature until analyzed. Extraction yield of each ethanolic and methanolic lipid fraction was calculated in terms of percent extraction yield and tabulated by the formula:

Extraction yield of lipid fraction $(\%)=$

Mass of essential oil $(g) \times 100$

Total mass of spice powder $(g)$

\section{Analytical methods \\ Antioxidant activity}

The free radical scavenging ability of 
the lipid fractions was determined using the method as described by Han, Weng, \& Bi, 2008. ${ }^{9}$ Two hundred microlitres of different concentrations $(10 \mu \mathrm{g} / \mathrm{ml}, 100 \mu \mathrm{g} / \mathrm{ml}$ and $250 \mu \mathrm{g} / \mathrm{ml}$ ) of lipid fractions was mixed with $2.7 \mathrm{ml}$ of $0.06 \mathrm{mM}$ methanolic solution of DPPH (2,2- diphenyl - 1-picryl - hydrazyl). The absorbance of the resulting mixture was measured after 15 minutes at $517 \mathrm{~nm}$ using UV-Vis spectrophotometer (JascoV670 UV-VIS-NIR Spectrophotometer Tokyo, Japan).

\section{Determination of total phenolic content}

The concentration of total phenols in lipid fractions was analysed using FolinCiocalteu Micro method; Waterhouse $2002{ }^{10}$ and calibrating with standard curve of gallic acid. Briefly, $20 \mu \mathrm{L}$ of lipid fraction was mixed with $1.58 \mathrm{ml}$ of distilled water and $100 \mu \mathrm{L}$ of Folin-Ciocalteu reagent. The mixture was homogenized completely and incubated for $8 \mathrm{~min}$. Subsequently, $300 \mu \mathrm{L}$ of aqueous $15 \%$ sodium bicarbonate was added, and the mixture was allowed to stand for 120 minutes with intermittent shaking. The absorbance was measured at $765 \mathrm{~nm}$ using a UV-Vis spectrophotometer (JascoV-670 UV-VIS-NIR Spectrophotometer Tokyo, Japan). Total phenolic concentration was expressed as gallic acid equivalent in $\mathrm{mg}$ per gram of lipid fraction.

\section{Determination of total flavonoid content}

Total flavonoid content was dictated by a colorimetric technique portrayed beforehand by Hajlaoui et al., 2009. ${ }^{11}$ Lipid fraction $(250 \mu \mathrm{L})$ was diluted with $1250 \mu \mathrm{L}$ of distilled water followed by the addition of $75 \mu \mathrm{L}$ of a $5 \% \mathrm{NaNO}_{2}(\mathrm{w} / \mathrm{v})$ solution. After 6 minutes, $150 \mu \mathrm{L}$ of a $10 \% \mathrm{AlCl}_{3} \cdot 6 \mathrm{H}_{2} \mathrm{O}$ $(\mathrm{w} / \mathrm{v})$ solution was added, and the blend was permitted to remain for another 5 minutes. Five hundred microliters of $1 \mathrm{M} \mathrm{NaOH}$ was added, and the aggregate was made up to $2.5 \mathrm{ml}$ with distilled water. The absorbance was measured against the blank at $510 \mathrm{~nm}$ utilizing a UV-Vis spectrophotometer (JascoV-670

UV-VIS-NIR Spectrophotometer Tokyo, Japan) in correlation with known Quercetin standard.

\section{Total flavonol content}

Total flavonols in the lipid fractions were evaluated utilizing the strategy reported beforehand by Hajlaoui et al., 2009. ${ }^{11}$ To $2000 \mu \mathrm{L}$ of lipid fraction at different concentrations $(10 \mu \mathrm{g} / \mathrm{ml}, 100 \mu \mathrm{g} / \mathrm{ml}$ and 250 $\mu \mathrm{g} / \mathrm{ml}), 2000 \mu \mathrm{L} \mathrm{AlCl}_{3}(2 \% \mathrm{w} / \mathrm{v}$ in ethanol) and $3000 \mu \mathrm{L}(50 \mathrm{~g} / \mathrm{L})$ sodium acetic acid solution was included. The blend was shaken and hatched for 2.5 hours at $20^{\circ} \mathrm{C}$. Absorbance was measured at $440 \mathrm{~nm}$. Total flavonols were communicated as $\mathrm{mg}$ of quercetin counterparts per gram of dry weight (mg QE/ml of lipid fraction) utilizing the calibration curve with quercetin.

\section{Determination of antibacterial activity Bacterial cultures}

Five food borne pathogens (Escherichia coli ATCC 8739, Vibrio parahaemolyticus ATCC 17802, Listeria monocytogenes ATCC 13932, Bacillus cereus ATCC 11778 and Vibrio alginolyticus ATCC 17749) were selected as test microorganisms. The cultures were grown overnight on nutrient agar plates for 16 hours and next day a loopful of each test bacteria were inoculated in $3 \mathrm{ml}$ of Mueller Hinton broth and were incubated at $37^{\circ} \mathrm{C}$ until turbidity of $0.5\left(1.5 \times 10^{8}\right.$ $\mathrm{CFU} / \mathrm{ml}$ ) Mcfarland index was achieved.

\section{Lipid fraction dilutions}

Lipid fractions of black seeds, fennel, bay leaf and coriander seeds were diluted in $40 \%$ DMSO according to the method of Martins et al. 2013. ${ }^{12}$ The concentrations of the lipid fractions used were $1000 \mu \mathrm{g} / \mathrm{ml}$, $500 \mu \mathrm{g} / \mathrm{ml}, \quad 250 \mu \mathrm{g} / \mathrm{ml}, 125 \mu \mathrm{g} / \mathrm{ml}$ and $62.5 \mu \mathrm{g} / \mathrm{ml}$. For the bioassay, the stock solutions of lipid fractions were sterilized by filtration using sterile membrane filters.

\section{Antibacterial test using the agar well diffu- sion method}

The antibacterial activity of the lipid fractions was determined by the agar well diffusion method proposed by Martins et al. $2013 .{ }^{12}$

\section{Drop agar diffusion method}

Antibacterial activity of the selected lipid fractions was determined by drop agar diffusion method as previously described by Lopes-Lutz, Alviano, Alviano, \& Kolodziejczyk, 2008. ${ }^{13}$

\section{Determination of minimum inhibitory concentration}

Minimum inhibitory concentration is generally considered as a measure of antimicrobial performance of LFs.
Determination of MIC assay was accomplished as described by Weerakkody et al. $2010 .{ }^{14}$

Analysis of disruption in cellular morphology using Scanning electron microscopy

Selected bacteria were standardized to a 0.5 Mcfarland scale and incubated for $18 \mathrm{~h}$ at $35^{\circ} \mathrm{C}$. Same strains were exposed to lipid fractions at $\mathrm{MIC}$ overnight at $35^{\circ} \mathrm{C}$. After $18 \mathrm{~h}$ of incubation, $10 \mu \mathrm{l}$ of crystal violet was added to Eppendorf tubes and left for $1 \mathrm{~min}$. Subsequently, the content of the tubes was washed with $70 \%, 80 \%$ and $90 \%$ ethanol and centrifuged at $13000 \mathrm{rpm}$ for $10 \mathrm{~min}$ each. The bacterial cells were coated up to $300^{\circ} \mathrm{A}$ with gold and viewed under SEM (JSM-6380A) at Centralized Science Laboratories, University of Karachi.

\section{Statistical analysis}

Analysis of variance was employed to compute significant differences between the means, and Duncan's test at $\mathrm{P}<0.05$ was used to separate means using SPSS software (version 24, SPSS Inc., USA). Adobe photoshop was used to create canvas of SEM images.

\section{Results and Discussion \\ Extraction yield of lipid fractions}

Table 1 shows the respective percentage yield of different lipid fractions extracted from spices. The highest yield was observed for Nigella sativa lipid fraction with the value of $43 \%$. Lipid fractions were extracted at a fixed temperature by methanol and ethanol solvents. These two solvents differ in their relative abilities to extract different bioactive constituents from the herbs and spices. On general basis, percentage yield of ethanolic lipid fractions was higher as compared to their counterparts. This signifies that the solvent ethanol has a better capability to percolate in the lipid rich cells and to extract out the lipid fraction ${ }^{15}$ (Table 2).

Table 1. Percentage yield of lipid fractions from dried condiments. ${ }^{a}$

\begin{tabular}{lcc} 
Condiments & \multicolumn{2}{c}{$\begin{array}{c}\text { Percentage yield (weight of lipid fraction: } \\
\text { weight of dried plant material w/w) } \\
\text { Methanol \% }\end{array}$} \\
Black seeds & $11.16 \pm 1.00^{\mathrm{a}}$ & $43.11 \pm 1.00^{\mathrm{d}}$ \\
Fennel & $30.46 \pm 1.00^{\mathrm{c}}$ & $26.70 \pm 1.00^{\mathrm{b}}$ \\
\hline Coriander seeds & $20.86 \pm 1.00^{\mathrm{b}}$ & $33.42 \pm 1.00^{\mathrm{a}}$ \\
Bay leaf & $12.22 \pm 1.00^{\mathrm{a}}$ & $12.93 \pm 1.00^{\mathrm{c}}$ \\
\hline
\end{tabular}

aValues are means of triplicates $\pm S D$. Values in the same column with different superscripts are significantly different at $P<0.05$. 


\section{Quantification of bioactive com- pounds}

Biologically active compounds namely phenolics, antioxidants, flavonoids and flavonols were estimated (Table 3).

\section{Estimation of total phenolic content}

Total phenolic content in lipid fractions prepared from above mentioned herbs was determined by Folin-Ciocalteu Micro method. ${ }^{16}$ The total phenolic content ranged from $0.82-5.40 \mathrm{mg} / \mathrm{L}$ gallic acid equivalents (Table 3). The phenolic content of methanolic LFs was higher for all the selected herbs except for fennel.

\section{Total antioxidant activity}

Antioxidant activity was determined using DPPH assay. DPPH (2,2-diphenyl-1picryl-hydrazyl) is a stable free radical and accepts an electron of hydrogen radical to become a stable diamagnetic molecule. ${ }^{17}$ When lipid fractions comprising of different proportions of antioxidants are reacted with the DPPH radical, the absorbance of the reaction mixture is decreased at $517 \mathrm{~nm} .{ }^{18}$ The highest radical scavenging activity was observed for ethanolic lipid fraction of coriander seeds. It was also observed that the percent scavenging activity also increased with the increasing concentration of lipid fractions (Table 2). The TPC showed a strong correlation with the DPPH scavenging abilities. The LFs which yielded higher TPC also had higher values for percent inhibition. Antioxidant activity was also evaluated as ascorbic acid equivalents with the highest activity observed for ethanolic lipid fraction of bay leaf.

\section{Total flavonoid and total flavonol content}

Total flavonoid and total flavonol content of all the LFs increased with the increasing concentration of LF. These results showed a significant relationship with that of TPC. Both yields of total flavonoid and total flavonols were higher of ethanolic LFs. Generally, ethanolic LFs had the highest antioxidant, TPC, flavonoid content and flavonol contents which indicated that the solvent ethanol has proven to be a better solvent to extract the lipophillic fractions hence bioactive components from herbs and spices. Another major benefit of

Table 2. Determination of percent DPPH scavenging effect of lipid fractions. ${ }^{\text {a }}$

\begin{tabular}{|c|c|c|c|c|}
\hline \multirow[t]{2}{*}{ Spices } & \multirow[t]{2}{*}{ Solvents } & \multicolumn{3}{|c|}{ Percent DPPH scavenging effect (percent inhibition) } \\
\hline & & 10 jlg/ml & $100 \mu \mathrm{g} / \mathrm{ml}$ & $250 \mathrm{\mu g} / \mathrm{ml}$ \\
\hline \multirow[t]{2}{*}{ Black seeds } & Methanol & $64.67 \pm 0.94^{c}$ & $87.60 \pm 1.11^{b}$ & $97.62 \pm 1.10^{\mathrm{b}}$ \\
\hline & Ethanol & $61.60 \pm 1.05^{\mathrm{a}}$ & $80.54 \pm 1.06^{\mathrm{a}}$ & $90.45 \pm 1.01^{\mathrm{b}}$ \\
\hline \multirow[t]{2}{*}{ Fennel seeds } & Methanol & $60.47 \pm 1.19^{b}$ & $68.27 \pm 0.94^{\mathrm{a}}$ & $76.21 \pm 1.03^{\mathrm{a}}$ \\
\hline & Ethanol & $90.36 \pm 1.10^{\mathrm{d}}$ & $93.40 \pm 1.13^{b}$ & $94.68 \pm 1.12^{\mathrm{c}}$ \\
\hline \multirow[t]{2}{*}{ Coriander seeds } & Methanol & $50.36 \pm 1.29^{\mathrm{a}}$ & $68.38 \pm 0.71^{\mathrm{a}}$ & $74.70 \pm 1.01^{\mathrm{a}}$ \\
\hline & Ethanol & $64.55 \pm 1.15^{\mathrm{b}}$ & $97.61 \pm 1.10^{c}$ & $99.59 \pm 1.04^{\mathrm{d}}$ \\
\hline \multirow[t]{2}{*}{ Bay leaf } & Methanol & $87.49 \pm 0.85^{\mathrm{d}}$ & $88.40 \pm 1.03^{b}$ & $99.38 \pm 1.07^{\mathrm{b}}$ \\
\hline & Ethanol & $33.89 \pm 0.98^{c}$ & $64.67 \pm 0.94^{\mathrm{a}}$ & $92.26 \pm 1.17^{\mathrm{a}}$ \\
\hline
\end{tabular}

aValues are means of triplicates $\pm S D$. Values in the same column with different superscripts are significant at $P<0.05$.

Table 3. Total phenolic, total antioxidant, total flavonoid and total flavonol contents of lipid fractions of condiments. ${ }^{\mathrm{a}}$

\begin{tabular}{|c|c|c|c|c|c|c|c|c|c|c|c|}
\hline \multirow[t]{2}{*}{ Spices } & \multirow[t]{2}{*}{ Solvent } & \multirow{2}{*}{$\begin{array}{l}\text { Total phenolic } \\
\text { content GAE (mg/L) } \\
\text { mg/100g dry weight } \\
\text { Un-diluted }\end{array}$} & \multicolumn{3}{|c|}{$\begin{array}{l}\text { Total antioxidant content AAE } \\
\text { (Ascorbic acid equivalent) }\end{array}$} & \multicolumn{3}{|c|}{$\begin{array}{l}\text { Total flavonoid content } \\
\text { ( } \mathrm{mg} / \mathrm{ml})\end{array}$} & \multicolumn{3}{|c|}{$\begin{array}{l}\text { Total flavonol content } \\
(\mathrm{mg} / \mathrm{ml})\end{array}$} \\
\hline & & & 10 $\mathrm{\mu g} / \mathrm{ml}$ & $100 \mu \mathrm{g} / \mathrm{ml}$ & $250 \mu \mathrm{g} / \mathrm{ml}$ & $10 \mu \mathrm{g} / \mathrm{ml}$ & $100 \mu g / m l$ & $\mathrm{Ig} / \mathrm{ml}$ & $10 \mu \mathrm{g} / \mathrm{ml}$ & $100 \mu \mathrm{g} / \mathrm{ml}$ & $250 \mu \mathrm{g} / \mathrm{ml}$ \\
\hline Black seeds & $\begin{array}{l}\text { Methanol } \\
\text { Ethanol }\end{array}$ & $\begin{array}{l}3.12 \pm 0.20^{c} \\
2.15 \pm 0.66^{b}\end{array}$ & $\begin{array}{l}15.46 \pm 0.97^{a} \\
20.12 \pm 1.02^{b}\end{array}$ & $\begin{array}{l}15.52 \pm 0.74^{\mathrm{a}} \\
20.53 \pm 0.93^{\mathrm{a}}\end{array}$ & $\begin{array}{l}23.78 \pm 1.01^{b} \\
20.43 \pm 0.77^{a}\end{array}$ & $\begin{array}{c}149.73 \pm 0.80^{b} \\
257.8 \pm 1.00^{b}\end{array}$ & $\begin{array}{l}191.33 \pm 0.70^{\mathrm{a}} \\
265.53 \pm 1.41^{\mathrm{b}}\end{array}$ & $\begin{array}{l}249.50 \pm 0.98^{\mathrm{a}} \\
558.30 \pm 1.25^{\mathrm{b}}\end{array}$ & $\begin{array}{c}94.60 \pm 1.01^{\mathrm{a}} \\
835.56 \pm 1.00^{\mathrm{d}}\end{array}$ & $\begin{array}{l}232.70 \pm 0.95^{\mathrm{b}} \\
878.40 \pm 0.87^{\mathrm{d}}\end{array}$ & $\begin{array}{l}294.63 \pm 1.15^{\mathrm{a}} \\
978.60 \pm 1.11^{\mathrm{d}}\end{array}$ \\
\hline Fennel & $\begin{array}{l}\text { Methanol } \\
\text { Ethanol }\end{array}$ & $\begin{array}{l}1.78 \pm 0.06^{b} \\
5.09 \pm 0.20^{c}\end{array}$ & $\begin{array}{l}17.96 \pm 0.99^{b} \\
20.62 \pm 1.41^{b}\end{array}$ & $\begin{array}{l}18.86 \pm 1.10^{b} \\
22.63 \pm 1.06^{c}\end{array}$ & $\begin{array}{l}18.94 \pm 1.00^{b} \\
22.68 \pm 0.94^{b}\end{array}$ & $\begin{array}{c}146.46 \pm 1.32^{\mathrm{a}} \\
123.0 \pm 1.00^{\mathrm{a}}\end{array}$ & $\begin{array}{l}232.63 \pm 0.97^{b} \\
220.76 \pm 1.00^{a}\end{array}$ & $\begin{array}{l}307.60 \pm 0.91^{\mathrm{b}} \\
317.70 \pm 1.08^{\mathrm{a}}\end{array}$ & $\begin{array}{l}139.45 \pm 1.03^{b} \\
190.60 \pm 1.03^{b}\end{array}$ & $\begin{array}{l}451.63 \pm 1.22^{d} \\
622.53 \pm 0.90^{c}\end{array}$ & $\begin{array}{l}981.36 \pm 1.25^{d} \\
815.56 \pm 1.15 c\end{array}$ \\
\hline Coriander seeds & $\begin{array}{l}\text { Methanol } \\
\text { Ethanol }\end{array}$ & $\begin{array}{l}3.23 \pm 0.15^{c} \\
1.89 \pm 0.40^{b}\end{array}$ & $\begin{array}{l}17.34 \pm 0.80^{b} \\
16.37 \pm 0.83^{a}\end{array}$ & $\begin{array}{l}17.42 \pm 0.782^{a, b} \\
21.62 \pm 1.12^{a, b}\end{array}$ & $\begin{array}{l}17.65 \pm 1.41^{\mathrm{a}} \\
22.68 \pm 1.06^{\mathrm{b}}\end{array}$ & $\begin{array}{l}318.30 \pm 1.25 \\
809.70 \pm 1.05^{\mathrm{d}}\end{array}$ & $\begin{array}{l}445.70 \pm 1.05^{c} \\
887.63 \pm 1.15^{d}\end{array}$ & $\begin{array}{l}497.60 \pm 1.10^{c} \\
531.63 \pm 1.15^{b}\end{array}$ & $\begin{array}{l}179.26 \pm 1.05^{\mathrm{d}} \\
249.60 \pm 0.95^{\mathrm{c}}\end{array}$ & $\begin{array}{l}280.50 \pm 0.95^{\mathrm{c}} \\
280.73 \pm 1.00^{\mathrm{a}}\end{array}$ & $\begin{array}{l}560.60 \pm 1.27 c \\
925.90 \pm 6.67\end{array}$ \\
\hline Bay leaf & $\begin{array}{l}\text { Methanol } \\
\text { Ethanol }\end{array}$ & $\begin{array}{c}1.20 \pm .055^{\mathrm{a}} \\
0.83 \pm 0.002^{\mathrm{a}}\end{array}$ & $\begin{array}{l}21.52 \pm 0.93^{c} \\
23.62 \pm 1.22^{c}\end{array}$ & $\begin{array}{l}22.63 \pm 1.45^{c} \\
25.70 \pm 1.10^{d}\end{array}$ & $\begin{array}{l}33.49 \pm 0.86^{c} \\
36.39 \pm 0.67 c\end{array}$ & $\begin{array}{l}328.23^{\mathrm{d}} \pm 0.80 \\
139.44 \pm 1.11^{\mathrm{a}}\end{array}$ & $\begin{array}{l}394.50 \pm 0.98^{b} \\
341.46 \pm 1.05^{b}\end{array}$ & $\begin{array}{l}576.23 \pm 1.16^{\mathrm{d}} \\
343.64 \pm 1.10^{\mathrm{a}}\end{array}$ & $\begin{array}{l}163.73 \pm 1.04^{c} \\
424.26 \pm 0.64^{c}\end{array}$ & $\begin{array}{l}196.36 \pm 1.02^{\mathrm{a}} \\
512.56 \pm 1.15^{\mathrm{c}}\end{array}$ & $\begin{array}{l}738.70 \pm 1.05^{d} \\
662.80 \pm 6.68 \mathrm{c}\end{array}$ \\
\hline
\end{tabular}

avalues are means of triplicates \pm SD. Values in the same column with different superscripts are significantly different at $\mathrm{P}<0.05$.

Table 4. Antibacterial activity of lipid fractions of black seeds, fennel, coriander seeds and bay leaf (un-diluted) by drop agar diffusion method.a

\begin{tabular}{|c|c|c|c|c|c|c|c|c|}
\hline \multirow[t]{2}{*}{$\begin{array}{l}\text { Food pathogens } \\
\text { tested }\end{array}$} & \multicolumn{2}{|c|}{ Black seeds } & \multicolumn{4}{|c|}{$\begin{array}{c}\text { Fennel } \\
\text { Growth inhibition (in mm) of lipid fractions }\end{array}$} & \multicolumn{2}{|c|}{ Bay leaf } \\
\hline & Methanol & Ethanol & Methanol & Ethanol & Methanol & Ethanol & Methanol & Ethanol \\
\hline Escherichia coli ATCC 8739 & $7.23 \pm 1.14$ & $10.52 \pm 1.08$ & $10.55 \pm 0.62$ & $9.27 \pm 1.12$ & $13.60 \pm 1.69$ & $17.45 \pm 1.63$ & $8.31 \pm 1.24$ & $15.14 \pm 1.00$ \\
\hline Listeria monocytogenes ATCC 13932 & $9.06 \pm 1.03$ & $17.37 \pm 1.47$ & $11.23 \pm 0.81$ & $15.56 \pm 1.25$ & $15.59 \pm 1.55$ & $21.36 \pm 0.96$ & $8.33 \pm 1.51$ & $12.68 \pm 0.89$ \\
\hline Vibrio parahaemolyticus ATCC 17802 & $24.54 \pm 1.34$ & $26.13 \pm 0.80$ & $11.69 \pm 0.60$ & $24.57 \pm 1.00$ & $16.76 \pm 1.19$ & $18.57 \pm 1.40$ & $17.56 \pm 1.28$ & $16.23 \pm 0.88$ \\
\hline Vibrio alginolyticus ATCC 17749 & $7.53 \pm 1.19$ & $\mathrm{~N} / \mathrm{D}$ & $11.27 \pm 0.80$ & $\mathrm{~N} / \mathrm{D}$ & $16.61 \pm 1.12$ & $\mathrm{~N} / \mathrm{D}$ & $6.30 \pm 1.46$ & $12.34 \pm 1.47$ \\
\hline Bacillus cereus ATCC 11778 & $11.17 \pm 1.16$ & $14.6 \pm 0.75$ & $12.23 \pm 1.20$ & $11.56 \pm 1.39$ & $17.27 \pm 1.10$ & $16.97 \pm 1.46$ & $18.18 \pm 1.65$ & $12.69 \pm 0.71$ \\
\hline
\end{tabular}


using ethanol as a solvent is that in food systems it gets evaporated without leaving any residues.

\section{Antibacterial activity of lipid frac- tions}

Tables 4-8 summarizes the inhibition of microbial growth by tested lipid fractions. According to these results, the EO of black seeds had the highest antibacterial activity against Vibrio parahaemolyticus ATCC 17802. If the bioactive profiling is to be compared with the antibacterial activity, it could be suggested that the ethanolic EO of coriander seeds is richest in bioactive compounds and had the highest antibacterial activity against Escherichia coli ATCC 8739 and Listeria monocytogenes ATCC 13932. It could also be suggested that the lipid fractions richest in phenolic contents also had the highest antimicrobial activities. The activities of LFs by drop agar diffusion method depends on the relative capacities of EOs to diffuse through the agar medium. ${ }^{19}$ The more viscous the lipid fraction the more difficulty it faced to diffuse through the agar matrix. The highest zone of inhibition was observed for ethanolic lipid fraction of nigella seeds against Vibrio parahaemolyticus ATCC 17802. Macrobroth dilution method employs different concentrations of active compounds in broth medium. Among all the tested lipid fractions the lowest MIC of $62.5 \mu \mathrm{g} / \mathrm{ml}$ was observed for ethanolic lipid fractions. These findings indicated that the ethanolic LFs were compatible with the MHB to successfully inhibit the pathogenic bacteria as compared to their counterparts. Agar well diffusion method is widely used to evaluate antibacterial activities of plant decoctions and is mainly dependent upon their relative polarities. The ethanolic LF of black seeds showed antibacterial action against all the tested food borne pathogens with a MIC of $250 \mu \mathrm{g} / \mathrm{ml}$ except for Listeria monocytogenes ATCC 13932 with an MIC of $1000 \mu \mathrm{g} / \mathrm{ml}$. The differences in MICs when evaluated using well diffusion and broth dilution method are due to the differential diffusion of the antibacterial compounds through the agar medium in the case of well diffusion method. Most of these compounds had lower polarities and therefore, were unable to cross the agar barrier and didn't show any bacterial growth inhibition despite of the use of carrier compound i.e. $40 \%$ DMSO. Another reason of higher antimicrobial activities of ethanolic lipid fractions were their relative concentration of bioactive compounds. The plant polyphenols and phenolics have been shown to elicit antibacterial functions. The subclasses in polyphenols group which also have similar
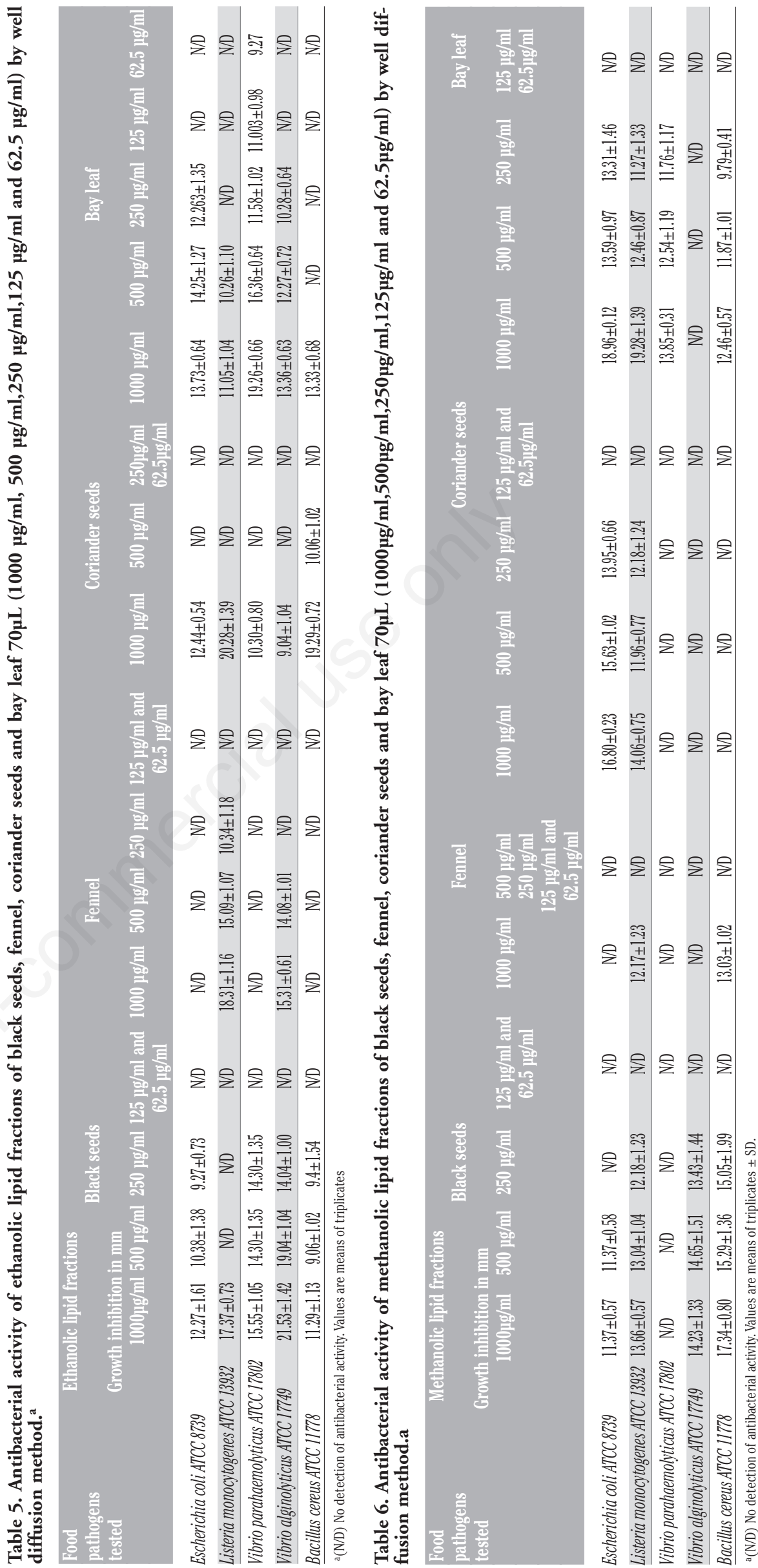
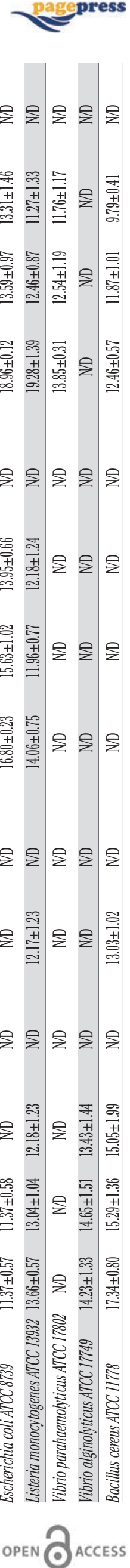
properties includes phenols, phenolic acids, flavonoids and flavonols etc. These compounds are produced by plant cells in defense to microbial invasion and therefore these elements have could kill a wide variety of microbes. ${ }^{20}$ The scanning electron microscopy images revealed the disruption in cellular morphology of tested pathogens when treated with LFs at MICs. Control cells were not exposed to these LFs (Figure 1 ). The changes in cell morphology were clearly visible in all treated pathogens with the LFs, in which formation of pores in cell wall and destruction of the bacterial cells were evident. Some researchers reported the effects of treatment with lipid fractions as cell wall disruption, damage to cellular membrane, membrane proteins, effusion of intracellular material, condensation of cytoplasmic fluid and reduction of proton motive force. ${ }^{21}$ Based on the results obtained from the changes in morphology, it can be postulated that the main target sites of these lipid fractions were cell wall and cell membrane of tested bacteria. It can also be hypothesized that the possible mechanism of action of these lipid fractions may involve termination of $\mathrm{N}$-acetyl muramic acid linkages, which would subsequently halt the synthesis of cell wall. ${ }^{22}$ In the nutshell, the findings obtained in this study indicated that ethanol is a solvent of choice to extract lipid fractions that will be rich in polyphenols, antioxidant compounds and will also be effective to inhibit the selected food pathogens in lower concentrations.

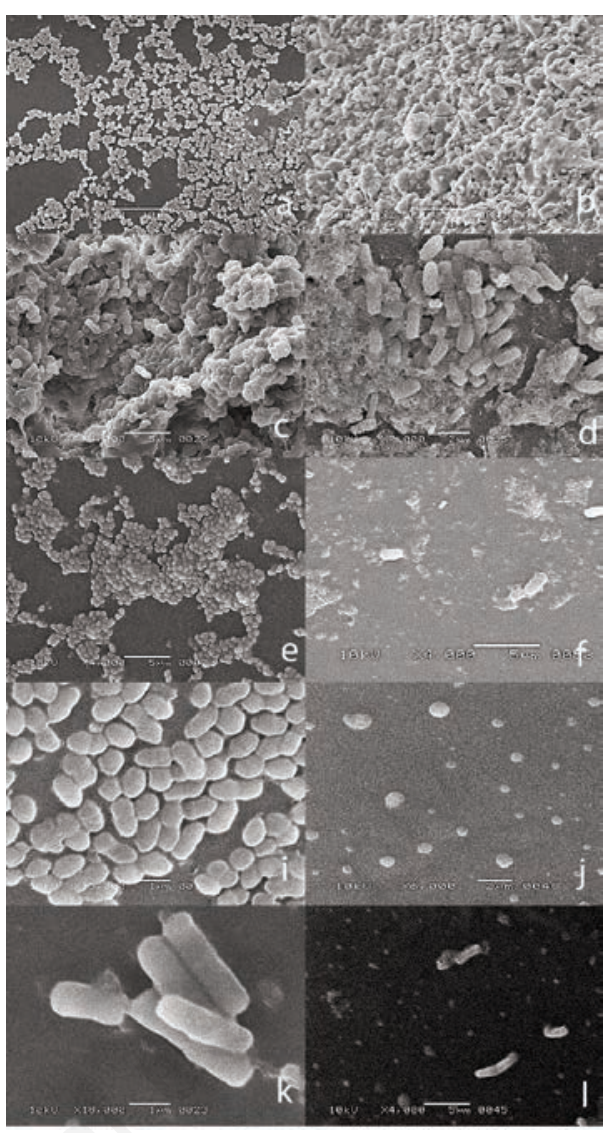

Figure 1. Scanning electron microscopic images of tested bacteria when treated with lipid fractions at MIC. Escherichia coli ATCC 8739 (A) control (B) treated with ethanolic lipid fraction of nigella seeds at $250 \mu \mathrm{g} / \mathrm{ml}$, Bacillus cereus ATCC 11778 (C) control (D) treated with ethanolic lipid fraction at $250 \mu \mathrm{g} / \mathrm{ml}$, Vibrio alginolyticus ATCC 17749 (E) control (F) treated with ethanolic lipid fraction at $250 \mu \mathrm{g} / \mathrm{ml}$, Vibrio parabaemolyticus ATCC $17802(\mathrm{G})$ control $(\mathrm{H})$ treated with ethanolic lipid fraction of coriander at $1000 \mu \mathrm{g} / \mathrm{ml}$ and Listeria monocytogenes ATCC 13932 (I) control (J) treated with ethanolic essential of bay leaf at $1000 \mu \mathrm{g} / \mathrm{ml}$.

Table 7. Minimum Inhibitory concentration (MIC) determined by Macrobroth dilution method. ${ }^{a}$

\begin{tabular}{|c|c|c|c|c|c|c|c|c|}
\hline \multirow{3}{*}{$\begin{array}{l}\text { Food pathogens } \\
\text { tested }\end{array}$} & \multicolumn{8}{|c|}{ MIC of Lipid fractions ( $\mathrm{\mu g} / \mathrm{ml})$} \\
\hline & \multicolumn{2}{|c|}{ Black seeds } & \multicolumn{2}{|c|}{ Fennel } & \multicolumn{2}{|c|}{ Coriander seeds } & \multicolumn{2}{|c|}{ Bay leaf } \\
\hline & Methanol & Ethanol & Methanol & Ethanol & Methanol & Ethanol & Methanol & Ethanol \\
\hline Escherichia coli ATCC 8739 & 500 & 62.5 & $\mathrm{~N} / \mathrm{D}$ & 62.5 & $\mathrm{~N} / \mathrm{D}$ & 62.5 & $\mathrm{~N} / \mathrm{D}$ & 62.5 \\
\hline Listeria monocytogenes ATCC 13932 & 1000 & 62.5 & $\mathrm{~N} / \mathrm{D}$ & 62.5 & 1000 & 62.5 & $\mathrm{~N} / \mathrm{D}$ & 62.5 \\
\hline Vibrio parahaemolyticus ATCC 17802 & 1000 & 62.5 & $\mathrm{~N} / \mathrm{D}$ & 62.5 & $\mathrm{~N} / \mathrm{D}$ & 62.5 & $\mathrm{~N} / \mathrm{D}$ & 62.5 \\
\hline Vibrio alginolyticus ATCC 17749 & $\mathrm{~N} / \mathrm{D}$ & 62.5 & $\mathrm{~N} / \mathrm{D}$ & $\mathrm{N} / \mathrm{D}$ & 1000 & 62.5 & $\mathrm{~N} / \mathrm{D}$ & 62.5 \\
\hline Bacillus cereus ATCC 11778 & $\mathrm{~N} / \mathrm{D}$ & 62.5 & $\mathrm{~N} / \mathrm{D}$ & 62.5 & 1000 & $\mathrm{~N} / \mathrm{D}$ & $\mathrm{N} / \mathrm{D}$ & 62.5 \\
\hline
\end{tabular}

a(N/D) No detection of antimicrobial activity hence no MIC.

Table 8. Minimum Inhibitory concentration (MIC) determined by well diffusion method. ${ }^{\mathrm{a}}$

\begin{tabular}{|c|c|c|c|c|c|c|c|c|}
\hline \multirow{3}{*}{$\begin{array}{l}\text { Food pathogens } \\
\text { tested }\end{array}$} & \multicolumn{8}{|c|}{ MIC of lipid fractions ( $(\mu \mathrm{rg} / \mathrm{ml})$} \\
\hline & \multicolumn{2}{|c|}{ Black seeds } & \multicolumn{2}{|c|}{ Fennel } & \multicolumn{2}{|c|}{ Coriander seeds } & \multicolumn{2}{|c|}{ Bay leaf } \\
\hline & Methanol & Ethanol & Methanol & Ethanol & Methanol & Ethanol & Methanol & Ethanol \\
\hline Escherichia coli ATCC 8739 & 500 & 250 & $\mathrm{~N} / \mathrm{D}$ & $\mathrm{N} / \mathrm{D}$ & 250 & 1000 & 250 & 250 \\
\hline Listeria monocytogenes ATCC 13932 & 250 & 1000 & 1000 & 250 & 250 & 1000 & 250 & 500 \\
\hline Vibrio parahaemolyticus ATCC 17802 & $\mathrm{~N} / \mathrm{D}$ & 250 & $\mathrm{~N} / \mathrm{D}$ & $\mathrm{N} / \mathrm{D}$ & $\mathrm{N} / \mathrm{D}$ & 1000 & 250 & $\mathrm{~N} / \mathrm{D}$ \\
\hline Vibrio alginolyticus ATCC 17749 & 250 & 250 & $\mathrm{~N} / \mathrm{D}$ & 500 & N/D & 1000 & $\mathrm{~N} / \mathrm{D}$ & 250 \\
\hline Bacillus cereus ATCC 11778 & 250 & 250 & 1000 & $\mathrm{~N} / \mathrm{D}$ & $\mathrm{N} / \mathrm{D}$ & 500 & 250 & 1000 \\
\hline
\end{tabular}

a(N/D) No detection of antimicrobial activity hence no MIC. 
5. Demetzos C, Perdetzoglou DK, Tan K. Composition and antimicrobial studies of the oils of Origanum calcaratum Juss. and O. scabrum Boiss. et Heldr. from Greece. J. Essent. Oil Res. 2001;13(6):460-2.

6. Battikh H, Bakhrouf A, Ammar E. Antimicrobial effect of kombucha analogues. LWT- Food Sci. Technol. 2012;47(1):71-7.

7. Oussalah M, Caillet S, Saucier L, Lacroix M. Inhibitory effects of selected plant essential oils on the growth of four pathogenic bacteria: E. coli O157: H7, Salmonella typhimurium, Staphylococcus aureus and Listeria monocytogenes. Food cont. 2007;18(5):414-20.

8. Cheikh-Rouhou S, Besbes S, Hentati B, Blecker C, Deroanne C, Attia H. Nigella sativa L.: Chemical composition and physicochemical characteristics of lipid fraction. Food chem. 2007;101(2):673-81.

9. Han J, Weng X, Bi K. Antioxidants from a Chinese medicinal herbLithospermum erythrorhizon. Food chem. 2008;106(1):2-10.

\section{References}

1. Roby MHH, Sarhan MA, Selim KA-H, Khalel KI. Evaluation of antioxidant activity, total phenols and phenolic compounds in thyme (Thymus vulgaris L.), sage (Salvia officinalis L.), and marjoram (Origanum majorana L.) extracts. Ind. Crops Prod. 2013;43:82731.

2. Davidson PM, Taylor TM, Schmidt SE. Chemical preservatives and natural antimicrobial compounds. Food microbiology: American Society of Microbiology; 2013. p. 765-801.

3. Araujo C, Sousa M, Ferreira M, Leao C. Activity of essential oils from Mediterranean Lamiaceae species against food spoilage yeasts. J. Food Prot. ®. 2003;66(4):625-32.

4. Davidson PM, Sofos JN, Branen AL. Antimicrobials in food: CRC press; 2005.
2008;69(8):1732-8.

14. Weerakkody NS, Caffin N, Turner MS, Dykes GA. In vitro antimicrobial activity of less-utilized spice and herb extracts against selected food-borne bacteria. Food Cont. 2010;21(10):140814.

15. Do QD, Angkawijaya AE, Tran-Nguyen PL, Huynh LH, Soetaredjo FE, Ismadji $\mathrm{S}$, et al. Effect of extraction solvent on total phenol content, total flavonoid content, and antioxidant activity of Limnophila aromatica. J. Food Drug Anal. 2014;22(3):296-302.

16. Cicco N, Lanorte MT, Paraggio M, Viggiano M, Lattanzio V. A reproducible, rapid and inexpensive FolinCiocalteu micro-method in determining phenolics of plant methanol extracts. Microchem. J. 2009;91(1):107-10.

17. Oktay M, Gülçin İ, Küfrevioğlu Öİ. Determination of in vitro antioxidant activity of fennel (Foeniculum vulgare) seed extracts. LWT-Food Sci. and Tech. 2003;36(2):263-71.

18. Basar M, Hossain S, Sadhu S, Rahman M. A comparative study of antioxidant potential of commonly used antidiabetic plants in Bangladesh. Orient. Pharm. Exp. Med. 2013;13(1):21-8.

19. Valgas C, Souza SMd, Smânia EF, Smânia Jr A. Screening methods to determine antibacterial activity of natural products. Braz J Microbiol. 2007;38(2):369-80.

20. Manach C, Scalbert A, Morand C, Rémésy C, Jiménez L. Polyphenols: food sources and bioavailability. The American journal of clinical nutrition. 2004;79(5):727-47.

21. Moleyar V, Narasimham P. Antibacterial activity of essential oil components. Int J Food Microbiol. 1992;16(4):337-42.

22. Ginsberg C, Zhang Y-H, Yuan Y, Walker $\mathrm{S}$. In vitro reconstitution of two essential steps in wall teichoic acid biosynthesis. ACS chem. biol. 2006;1(1):25-8. 